\title{
Linfoma Primário De Pâncreas: Um Relato De Caso
}

\author{
Accorsi, B.F.; Tornatore, A.R.; Jornada, F.M.; \\ Apresentador: Angela Rosa Tornatore
}

\section{Resumo}

Introdução: A maioria dos Linfomas não-Hodgkin origina-se em linfonodos. Porém, cerca de $40 \%$ dos casos tem origem em sítios extranodais, desses, o TGI é o local mais envolvido, respectivamente estômago, intestino delgado e cólon, sendo o linfoma de pâncreas um evento raro, representando menos de $1 \%$ a $2 \%$ de todos os tumores malignos do pâncreas, e menos de $1 \%$ de todos os linfomas não-Hodgkin extranodais. Relato de Caso: FLC, 62 anos, previamente hígido, com história de emagrecimento, inapetência e astenia há 6 meses. Evoluiu com piora progressiva do quadro clínico, apresentando-se hipocorado, com hematomas em tórax e dor intensa em região de epigástrio e periumbilical, tendo chegado ao atendimento anúrico há 36 horas, com alteração importante de exames laboratoriais, anêmico, necessitando diálise. TC de abdome mostrou aumento difuso e homogêneo da cabeça pancreática, com indefinição dos planos de clivagem com a veia mesentérica inferior, além de múltiplos linfonodos no retroperitônio e junto aos vasos ilíacos bilateralmente. Fígado e baço sem alterações. Na biópsia, diagnosticou-se linfoma não Hodgkin (LNH) de cabeça de pâncreas, com células linfoides grandes, atípicas, pleomórficas, com nucléolo evidente, circundadas por grande quantidade de linfócitos pequenos entremeados de estroma esclerótico, confirmado por imunohistoquimica como LNH de grandes células B. Paciente foi estabilizado, iniciou-se corticoterapia e transferiu-se a outro hospital para iniciar quimioterapia. Discussão: O Linfoma de pâncreas é incomum. Conforme descrito por Behrns et al (1994), alguns critérios devem ser atendidos para sugerir que o linfoma é de origem pancreática e não um linfoma nodal que se estende ao pâncreas. Assim, um linfoma primário do pâncreas é definido como uma massa pancreática com envolvimento de gânglios linfáticos peripancreáticos sem envolvimento distal de gânglios linfáticos, nem metástases hepáticas ou esplênicas, e uma contagem de células brancas do sangue normal. O linfoma de pâncreas pode imitar o adenocarcinoma pancreático clínica e radiologicamente, por isso é importante a diferenciação entre os dois e o rápido início do tratamento oncológico agressivo.

\section{Referência:}

Accorsi, B.F.; Tornatore, A.R.; Jornada, F.M.;. Linfoma Primário De Pâncreas: Um Relato De Caso. In: II Congresso Brasileiro de Medicina Hospitalar - II CBMH [= Blucher Medical Proceedings, vol.1, num.5] São Paulo: Editora Blucher, 2014. p.100 DOI 10.5151/medpro-II-cbmh-100 